\title{
Miranda
}

Revue pluridisciplinaire du monde anglophone /

Multidisciplinary peer-reviewed journal on the English-

speaking world

$14 \mid 2017$

Early American Surrealisms, 1920-1940 / Parable Art

\section{Sands of desire : the Creative Restlessness of Lee Miller's Egyptian Period}

\section{Peter Schulman}

\section{OpenEdition}

\section{Journals}

\section{Electronic version}

URL: http://journals.openedition.org/miranda/9855

DOI: $10.4000 /$ miranda.9855

ISSN: 2108-6559

Publisher

Université Toulouse - Jean Jaurès

\section{Electronic reference}

Peter Schulman, "Sands of desire : the Creative Restlessness of Lee Miller's Egyptian Period", Miranda [Online], 14 | 2017, Online since 03 April 2017, connection on 16 February 2021. URL: http:// journals.openedition.org/miranda/9855 ; DOl: https://doi.org/10.4000/miranda.9855

This text was automatically generated on 16 February 2021.

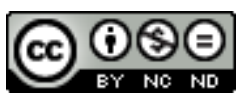

Miranda is licensed under a Creative Commons Attribution-NonCommercial-NoDerivatives 4.0 International License. 


\title{
Sands of desire : the Creative Restlessness of Lee Miller's Egyptian Period
}

\author{
Peter Schulman
}

\begin{abstract}
"As a spectator, I wanted to explore photography not as a question (a theme) but as a wound," Roland Barthes writes in Camera Lucida (Barthes 17). Similarly, in the famous first lines of his surrealist book Nadja, André Breton concluded that the question he should ask himself should be "not who I am, but whom I haunt" (Breton 7). Could either of these quotes apply to Lee Miller's aesthetic as well ? While her photographs during

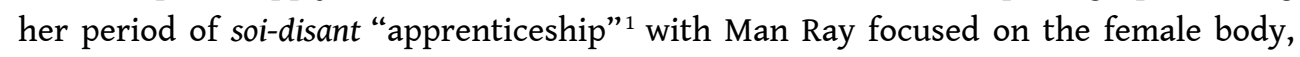
and the ones in her studio in New York on elegant portraiture, it is during her period in Egypt when she was married to the wealthy, older Egyptian businessman Aziz Eloui Bey that her photography truly blossomed into her own aesthetic which "married" the humor and the ludic notions of space found in certain Magritte paintings with the curious gaze of the 'other' that she would develop as a photo-journalist during the war. Her photos during her Egyptian period are filled with a restlessness and a thirst for adrenaline that would stoke her wartime experiences and push her to cry out "Shit, that's blown my first paragraph!" (Penrose 144) at the news of the German surrender ending World War II, and her role in it. As Aziz himself observed, Lee put on weight during her time in Cairo and developed an "Egyptian complex, which means being a spectator" (Burke 157). In terms of her photography, one might also consider that she gained a "metaphoric weight" in the sense that her own unsettled spectatorship could be transposed onto the curious rocks, sands, shapes and winds of the desert.
\end{abstract}

\section{Wandering Among the Sepulchers of the World}

2 After Lee left him for Aziz, it has been widely documented that Man Ray projected his anger and the feelings of betrayal he felt towards her in such works as Object of Destruction (1928), the metronome with Lee's eye at the tip of the needle or others such 
as the famous Lee Miller (1929) where Lee's neck and head are violently thrust into motion as if to suggest that she had just been struck. If for Man Ray, thanatos and eros were inexorably welded together as his art became somewhat violent when the erotic image that he sought to possess became unreachable, Lee Miller sought out the thanatos and infused it not only with surrealist wit, as in Remington Silent (1940), the photograph of a crushed typewriter after a German bombing raid on London, or the naked statue of Venus under the rubble in The Revenge on Culture (1940) from Grim Glory, her book chronicling the London Blitz, but with a melancholy worthy of Breton's notion of "haunting."

3 Although she chose to take pictures on the front lines, like such Great War photographers as Robert Capa, and put herself in danger rather than sit in the press room with the other journalists, she did so because she was fascinated by the beauty she often saw in the overwhelming sadness before her. As such, if under Man Ray's painting of the Marquis de Sade watching soldiers lay siege to a castle in flames, the inscription reads "ma mémoire s'effacera de l'esprit de l'homme"(“my memory will erase itself from Man's spirit", D.A.F. de Sade, 1938), Miller's attraction to ruined and empty battle spaces such as her picture of the Saint-Etienne cathedral in Vienna 1945 showing an exhausted soldier being dwarfed by the sunlit reflection of a spire, or the soprano Irmgard Seefried joyously singing in the ruins of the Vienna opera house, aims to make sure that her memory will not disappear once the war is over and Europe is reconstructed. Along similar lines, her photo of the Queen Mother Helen of Romania alone in a balcony of an empty theater underlines her fascination not with populated spaces but with abandoned and ruined ones which emerged in full during her Egyptian period.

4 While in Egypt, she felt compelled to seek out the desert as a reaction to her boredom with Egyptian upper-class society. She desperately wanted to get back into the thick of things in Paris where great art was being created. ${ }^{2}$ It was perhaps the anticipation of the boring, calm domestic life that was waiting for her after the war in England with her husband, Roland Penrose, that might have pushed her towards the frontlines where she was indeed once again in the middle of the action. Yet, her seemingly thanatosian Wanderlust as a correspondent might also suggest an inner haunting - whether on a personal level due to her continued need for sexual and emotional freedom - or on an artistic one, where daily human destruction created a beauté convulsive and an explosante fixe that the surrealists could only create artificially in their studios before the war. Perhaps, it is within this prism that Lee most resembles Man Ray's aesthetic. Far from his tutelage and domination, she was able to grasp what Janus, writing about Man Ray, describes in the following terms: "The photographer artist is the only one who attempts to bring [the cadaver] back to life, so he can pass it on to the future. [He] is the exorcist wandering among the sepulchers of the world, evoking what life never ceases losing" (Man Ray 14). Wandering through the sepulchers of her own world, Miller's photographic art becomes an existentialist quest as she never felt more alive than when she was surrounded by death. Sadly, her mournful images of war-torn Europe reflect her own melancholy in relation to the ephemeral and fleeting moments of the world history she was able to participate in, as she no doubt anticipated the end of her career once the action had stopped, and life became "normal" once again.

5 Certainly, flight and spontaneity were integral parts of Miller's life and work. She was introduced to the world of fashion-photography at Vogue Magazine in 1926 as a result of 
a certain stranger in a crowd of bystanders who grabbed her right when a car was about to run her over. The fact that that stranger happened to be Condé-Nast suddenly changed her life from a budding art student taking classes at New York's Art Student League to a famous cover girl. In 1929, with her best friend Tanja Ramm, she sailed to Paris, sought out Man Ray and became, despite his initial reluctance, his mistress and artistic partner. In 1931, as Man Ray became alarmingly attached to her, Miller instinctively felt the need to regain her own "space" both artistically and personally, and started an affair with Aziz whose inner calm and outward exoticism must have been incredibly appealing to her at that time. As Aziz and Miller became more and more romantically involved, utter chaos and destruction erupted around her as Man Ray became engulfed in a jealous frenzy and threatened to kill himself, and, tragically, Nimet, Aziz's beautiful and often photographed wife, in fact, did commit suicide. According to her son, Anthony Penrose, Miller had felt incredible guilt regarding the suicide and "took a great deal of trouble to obscure that part of her life" (Roumette). As these impassioned flames encircled her, she discreetly escaped back to New York at the end of 1932 to start her own photographic studio on East $48^{\text {th }}$ Street with her brother Erik. Framing famous actors and artists through relatively conventional portraiture may have given her a sense of control that stabilized her after her Parisian experiences went emotionally haywire. As Anthony Penrose explains :

Lee could not be controlled [...] Lee thought she was considered an 'appendage to Man Ray' and she wasn't going to be an appendage to anyone. She was afraid that her own creativity was being overshadowed by Man Ray, and that there was a danger that people were not seeing her as an individual [...], Lee decided that the only thing she could do was break away from this every tightening circle of admiring men trying to possess her and nail her down. (Roumette)

\section{Leaving the Disciplined Darkroom}

6 Yet, as she would soon find out, the pressures of a highly visible and fashionable studio of her own led to major shifts in her photography as well. For Jane Livingston, "New York was the true training ground for the rest of her life as a photographer - and was in itself the closest she came in a sustained way to being a fully disciplined darkroom craftsman in her medium, an artist who worked in a conventionally disciplined and formularized manner" (Livingston 43). Could Miller have conceived of her "disciplined darkroom" as another confining environment parallel to her relationships with controlling Parisian men? Perhaps, since in 1934, when Aziz showed up in New York, she decided once again to close shop that summer, abruptly marry him and move to Cairo. For Livingston, it is Miller's abandoning of the contained technological environment of the studio which favored her carefully arranged portraits of famous people in favor of more spontaneous, haphazard subjects that she found in the deserts of Egypt or later, magnified to its fullest, on the battlegrounds of Europe during World War II, that would produce her greatest photographs :

Oddly, and even inexplicably, Lee Miller would soon leave behind many of the stylistic characteristics she so laboriously honed in these early years. From 1935 on, her work shifted dramatically when the circumstances of her life took her away permanently, as it would turn out, from the luxury (or the discipline, or encumbrance) of an elaborately equipped studio and darkroom. (Livingston 46).

As Livingston sees it, the shift in technologies from a stationary darkroom to more portable equipment liberated her and allowed her to roam the world in search of more 
adventurous shots, on the one hand, and, on a personal level, made her more in tune with her deep-seated desires : "But there is a deeper need," Livingston explains, "one senses in her development as a photographer from now on - a desire increasingly to engage the world on its own terms, to clear away her own powerfully if subtly mediating taste, to allow her subjects to present themselves as their nature made them" (Livingston 46). Moreover, Burke notes that the portability of her Rolleiflex camera or the Leica miniature (favored by such contemporaneous photographers as Cartier-Bresson) that she carried around with her in Egypt facilitated the artistic flexibility she needed to explore the desert: "In time, her camera became a means of transport, a way to escape elite Cairo" (Burke160).

In a letter to her brother, however, shortly after having abruptly left him unemployed, she wrote of a lull in her photographic creativity that was rekindled only after a certain period of utter boredom and monotony caused by the tedious British High Society expatriates whose company she grew quickly weary of :

I sit around reading rotten detective stories, also playing a great deal of poker and bridge. I'm lousy at housekeeping. I just don't bother and when everything goes wrong, as it is sure to, I can get as good a laugh as anyone. I don't know if you're still interested in photography or got the same loathing for it I had had until Xmas time this year, I hadn't taken even a roll of film - all but three exposures I didn't even bother to develop. (Penrose 64-65)

9 Although she gave the marriage to Aziz a fighting chance for a year, learning to play golf and holding parties in their villa, she ultimately had to flee Egypt as well, eventually running off with the man who would be her future husband, Roland Penrose. Yet, through her photography, she was able to escape through her haunting images of flight mixed with confinement that would be emblematic of her life in Cairo. As Livingston concludes, "It was almost as though, in the mid 1930's, she began again to learn to be a photographer" (Livingston 45).

\section{Blockages}

10 As such, many of the images of her Egyptian period would be characterized by a combination of vast romantic spaces and often sexualized geometric images penetrating negative spaces such as her famous picture of the Great Pyramid's shadow over the plains of the Nile (1938) or the Monasteries of Dier (1936). In each photograph, a sense of emptiness is somehow governed by geometric forms which encourage a feeling of spectral "presence of absence." In the pyramid picture, the pyramid's shadow seems to truly rule over the landscape with its darkness and sharp edges, while the white rectangular monastery underlines a sense of desertion, or perhaps a ghostly flight leading one to wonder if there are or were monks inhabiting the deserted space. In such photographs as Street in Cairo, however, which at first lends itself to a typical representation of a lively street scene, the frame seems in fact to be sliced up by the "fluttering banners strung in zigzag patterns" (Livingston 481). The banners carve the shot as though it were a shattered mirror. It is as though the banners were able to exercise a visual control over what could have been a chaotic urban view. Similarly, in another street scene, a shadowy ghost of a figure, with a short turban and carrying unidentified merchandise, cuts through the picture frame in a furtive diagonal. If the pyramid seemed to exercise a ghostly grip over the plains which metaphorically could be positioned in a kneeling relation to it, as though they were vassals, Miller focuses on 
the merchant's motion, as he runs away from the viewer, while a figure, whose face is hidden behind a mask-like veil, looks on beneath a prison-like window. Indeed, the figure and the bars of the window are perpendicular in their axis to the fleeing merchant who will dissolve into the shadows in contrast to the ray of sunlight that dashes across the frame.

11 The theme of "windows" in Millers' work is particularly interesting in light of the role they play in the later Grim Glory and her war photography in which the scenes they frame are invariably centered around crumbling edifices or explosions. In Dolphin Court: London During the Blitz, for example, the wind seems to draw the window's curtain, as though for a puppet's theater, onto a building with a recently destroyed upper floor (1940). Similarly, in the famous Revenge on Culture (1940), a naked and sensual Grecian statue is lying diagonally across the frame with a brick on her breast as she clutches onto a fallen doorway. Sadly, she seems to have been struck by fallen rubble. During the Egyptian period, however, windows and diagonals are often associated with blockages or immobility. In Stairway, Cairo (1936), a diagonal old stairway splits the negative space in two as if to suggest that it is going nowhere, neither up nor down (rather than both up and down). The wall behind it is rather decrepit and has an ameba-shaped patch of black at its center as if to bring attention to the fact that there is some murky and ominous force at the foot of the staircase. The picture's emptiness in relation to Miller's Parisian period, for example, underscores the loneliness and feelings of stagnation that Miller felt within the rather superficial upper-class Egyptian and British society. Unlike the vibrant social and cultural network she had thrived in when she was a part of "Surrealist Paris" and New York, Cairo must have seemed like an intellectual prison to her despite Aziz's loving and patient care. Lee considered marriage to Aziz a type of confinement, despite her well-intentioned belief that she could make it work. She thought of herself as one of those "flagellant saints or hysterically repressed nuns who make a mystic marriage [...] I'm like a condemned person in a cell, full of self-pity, misery, and sexual excitement" (Burke177). Moreover, in a letter to Roland, she asserts : "I'm so bored here! I think that I'm slowly going mad." (Burke 179). As Aziz wrote in a letter to his children regarding Lee's adjustment to Cairo life: "Naturally, it is not easy to settle down smoothly considering her much troubled soul. Certain reactions are bound to happen. Only small things like being bored suddenly. You see, she does not work anymore and her brain must work to occupy Lee's time" (Penrose 61).

In a photo titled Cotton Struggling to Escape from Sacks to Become Clouds (1936), the frame is once again diagonally split in two with the sky on one side and fluffy cotton patches pushing their way out of rock-like sacs on the other. Again, one can read into their "struggle" a metaphor for Lee's own creativity fighting to break out of the mercantile sacks and into the freedom of the sky. In an untitled picture of snail shells in a tree, the canvas is also diagonally ripped in half by a thrusting branch. The background is of a completely blank sky and the rest of the branches fill the frame as though they were cobwebs. Nonetheless, the snail shells (about ten bleached circles) manage to climb undaunted up the branch. One snail crowns the tip of the branch at the tallest point of the picture as if to express Lee's underlying push towards her own conceptions of freedom - sexual, spatial, social - despite her feelings of emptiness within a framework of Egyptian domestic life. Indeed, the absence of humans in many of her Egyptian photographs reflect her vision of Egypt as "just tombs, ruins, and embalmed 
bodies" (Burke 183). As she puts it, the incessant routinization of her life there seemed utterly deathlike to her: "Generations of people, dead people doing exactly the same thing in the same way," she continues, "[...] The only thing that seems alive is the hope that I can get out of it" (Burke 183).

In fact, her dire images of social claustrophobia in Cairo are particularly graphic in such photos as the geometrically precise Monastery of Wadi Natrum: Doorway (1936) in which the cross above the door is framed by a wooden right angle resembling a hangman's gallows. As with many of her Egyptian pictures, there is a complete lack of humanity: only a mise-en-abyme of squares within squares (beginning with a tiny window then a door and then the hang-man-like wooden plank bracketed by rectangles and edges). In Blocked Doorway, Syria (1938), the blocked entrance is even more graphic, as large rocks fill the doorway so that no one can enter or leave the paralyzed structure. It is in stark contrast to her later Non- Conformist Chapel shot in London during the blitz in 1940 which conveys all the humor Lee could express even during the most extreme war-time conditions. The chapel she photographs is "non-conformist" because its doorway seems to be spewing hundreds of blocks of rubble. That doorway, unlike the Egyptian monastery or the blocked Syrian doorway, is alive with action and movement, despite, ironically, its context of destruction and bombardments. While Blocked Doorway and Non- Conformist Chapel both have doorways filled with large rocks, the fact that the London one is defined by a cascading motion, fresh from a violent aerial attack, highlights the opposing contexts of the two pictures and underlines the striking differences in Lee's conflicting "frames of mind." War-torn Europe represented an unbridled adventure for her, a "non-conformist" thrill, while Cairo life was its antithesis : Lee's free-spirited modus vivendi had been blocked by a Cairo upper-crust and bored society dictated by conformism and decorum.

\section{Purgatories}

The sensation of being locked-in by conformity is further evident in an unusual picture taken at the Red Sea titled Procession (1937). Unlike her photos in which emptiness seems to either share or dominate the background, Procession is as spatially blocked as the stairway wedged into a dark wall and leading nowhere, even though it presumably represents endless and sweeping waves of sand. By her title, Lee suggests that the hundreds of lines in the sand that are punctuated by circular, bullet-hole-like perforations, are in fact only following themselves, one after the other in a procession, like endless troops of soldiers. There are no spaces for escape, only, and predominantly, vertical lines of sand that, when the picture is looked at in its entirety, in fact form a series of prison bars. Whereas in a typical prison cell, the bars are spaced out with air and glimpses of freedom, the sand bars prevent any gasps of open spaces. There are only lines of sand in a continual procession with neither a break in sight nor a specific destination in mind; there is only an overwhelming purgatory sensation. This purgatory, of course, is also a manifestation of Lee's own ambivalence in addition to the oppression she felt in a gossip-obsessed milieu which, as opposed to Paris, monitored and observed every bit of quotidian minutia in Lee's life. As Burke writes :

Despite the sultriness of life in Cairo, sex outside of marriage

was unthinkable for Muslim women though some of their

husbands visited the brothels of the rue Clot By. Few risked their

positions by having an affair while they indulged themselves in 
other ways (eating sweets, playing cards, gossiping), a shared

sexual timidity kept women from venturing outside of the

haramlek. This fear along with the mentality of bourgeois Cairo-

where neighbors noted whose car was pushed outside whose abode-

created an atmosphere almost as claustrophobic as Poughkeepsie. (Burke169)

Noticing the absence of native people in much of her Egyptian work "whether as portrait subjects or anonymous figures," Livingston describes Lee's Egyptian period in terms of a type of abstraction for abstraction's sake :

The cotton bursting through the rounded burlap shapes becomes a kind of analog to the white clouds behind: the composition perfectly divides foreground and background into two realms, with a strong diagonal. The strange characters of textual lushness here become the very subject, or raison d'être, of the image, signaling a renewed attention to abstract visual content as an end in itself." (Livingston 48)

16 Lee's Egyptian period also seemed like an "abstract end in itself" as she was neither in New York, nor Paris, the two centers of her social and artistic universe. Egypt represented an "other" that was neither here nor there - a type of insipid British colony on the one hand in terms of social life; a land of adventure and mystery in terms of landscape and geography on the other. As a non-Muslim American wife in a social and cultural milieu she had no connection with, the abstractions offered by the desert could either be seen as a desire for hope and reverie or, in the case of the solid wall and stairway, a type of petrified prison, and complete lack, paradoxically, of "lightness of being." This type of spiritual lethargy is mirrored in her pictures of empty hotel bars, such as The Estate House of Abboud Pasha or Restaurant Table (1936) where immaculately ordered spaces meant for gregarious activity are populated only by inanimate objects such as bottles or puppets while stools and chairs seem to wait, wistfully, for someone to sit on them.

17 The emptiness in many of these scenes reflects a haunting and haunted aspect that reflected Lee's inner turmoil in Egypt. Since she felt trapped by the confines of the Egyptian high society she was forced to interact with, the desert and the excitement of a bustling Cairo provided for an artistic space of freedom and testing ground for her photographic expressions. While she searched for her own sense of identity during her Egyptian period, she was also searching for her artistic voice that would reach new heights during the war. Just like ghosts who supposedly haunt a space until they are at peace with themselves, Lee may have haunted her own Egyptian spaces until she was artistically and emotionally ready to plunge into the war-torn realities of Europe. As Katherine Conley affirms: "In their assured stillness, Miller's Egyptian landscapes announce the beginning of her mature work. They represent the stylistic synthesis of her earlier photographs, taken as a surrealist working with Ray in Paris and of those taken as the director of her own studio in New York," (Conley 98).

\section{Towards Freedom}

18 In perhaps Miller's most famous photograph, however, Portrait of Space (1937), the lack of any human or animate subject is underlined by a vast opening through what appears to be the aperture of a long mosquito net cum window onto a sandy desert landscape. Taken towards the later part of the Egyptian period, it is one of the only ones to be overtly surrealist in nature (and is considered to have inspired Magritte's painting Le 
Baiser when he saw Portrait of Space in a London gallery in 1938). It is one of the most airy of Miller's paintings, and while it is looking out onto a lunar-like landscape, the wind pushing the aperture sets a somewhat optimistic, dashing tone. As Lee might have felt her Egyptian period was soon coming to an end, one might read Portrait of Space as a type of "light at the end of the tunnel" for her Cairo Purgatory, if not a giant wish fulfillment for space and liberty. The blankness of the white desert can also be interpreted as a "Zen-like" purge of the populated but stressful life she led at the heart of the surrealist movement in Paris. The fact that the freedom implied by the desert scene is so vague also reinforces the notion that for Lee, the excitement of true freedom was inexorably linked to the unknown and to spontaneous impulses in general. The square, blank frame which gratuitously hangs at the top center of the picture adds an element of certainty, or even a faith in the target she is trying to capture. It also establishes a contrast between the restricted but blank world of the frame and the wild, unfathomable but ultimately promising world offered by the anonymity of the desert, a space that appears to be within reach of the viewer. This sensation is similarly apparent in her picture of Robin Fedden (1937), who appears gloriously in command of the desert's vastness, as though he were Lawrence of Arabia. His view is one of excitement and opportunity faced with a "blank slate" of possibility. Similar to the giant shadow cast by the pyramid, however, or the Cairo street scene, Miller slices the negative space up in edgy pieces of sunlight and darkness the isosceles position of the skis seem ready to pierce. In a reversal of the violent images Man Ray used to exact artistic revenge on Lee's perceived infidelities (such as his famous figure of the metronome with Lee's eyeball on the pointer, Object to be Destroyed, 1932), the V-shape of the skis are inviting and point to the shared adventures Fedden and Lee would enjoy during their escapades in the desert.

19 Slowly, the desert seems to have opened Lee to the possibilities of liberation. As Mark Haworth-Booth understands it : "In the desert her photography reconnected with her imagination and the visual sense she had cultivated in Paris (Haworth-Booth 124). In an untitled picture of dunes (plate \#100, Haworth-Booth 120), the frame is once again diagonally slit in half; yet, unlike such somber pictures as the snail shells surrounded by anxious branches or The Native, also known as Cock Rock (Western Desert, 1939) in which a jagged rock violently cuts through the frame like a dagger, the split is much more gentle in the photograph of the dunes. A romantic, ocean-like mass of sand appears ready to invade a more pristine, whitened expanse. The invasion is blocked by a horizontal, thick band of blackness, however - a shadowy strip that reminds the viewer that there is an obstacle to the freedom even though the potential for adventure and expansion is visibly apparent. The horizon, often represented in Romantic poetry as a symbol for a lack of limitations, is, in Lee's Egyptian iconography, a barrier for imagination and movement.

The gradual freeing of Lee's aperture reflected her own possibilities for flight that were progressively presenting themselves to her. As Burke recounts, her trips with Fedden and friends such as Mary Anita Loos (Anita Loos's niece) with whom she felt free to frolic in the powdery desert (often on skis), were an "antidote to boredom" in Burke's eyes. "My current ambition," Lee confirms to Roland in a letter, "is to have my own racing camel - do it up very fine in my own colors and ride it around wearing a galaby" (Burke 185). A part of her clearly yearned for the exotic travels undertaken by such free spirits as Freya Stark or Emily Hahn for whom nothing could be more antithetical than 
the vapid high society Lee felt chained to. "For Lee," Burke concludes, "the desert became a place where she could see more clearly. Who she was - and see herself seeing" (187). In this way, the spectatorship Aziz included as an integral part of her "Egyptian complex" could also be reversed onto the artist herself who, while never appearing in any of the pictures she took, was always present in their état d'âme. If, in the beginning of her Egyptian period, people were absent and replaced by geometric shapes, angles, frames and an eerie immobility, her later ones seem to move towards a more serene period characterized by an increase in open spaces. Indeed, she must have considered her love for Penrose an appealing one-way ticket out of Egypt as she clearly states in one of her letters to him: "I'm never returning to Egypt unless the ultimate of disasters or dejection overcome me. I'm glad that I'm finally coming back to you" (Burke 193). It is not surprising that one of the most elegant and romantic photos of her Egyptian period is in fact of Roland himself in 1939, on the eve of another European war (plate \# 117, Haworth-Booth 132). As usual, the frame is diagonally split, although not in the middle like most of her shots of inanimate objects or plants, but on the far left of the frame. Penrose is seen gazing past the set of white stairs that bracket him (the stairs and their diagonal shadow). As opposed to the vertical stairway going nowhere and encased in a gray morass surrounding the caged window in Stairway, Cairo, Penrose looks out at layers of vegetation and a sun-drenched desert. The sky, which takes up three quarters of the picture as a whole, is a somewhat cheerful element rather than a bleak one. It is as though Penrose were looking out upon a future of expectation and promise instead of the existential dread implied by the drab empty backgrounds of the earlier pictures. Moreover, his humanity, similar to Fedden's, brings an additional warmth and excitement to the photograph as a whole that the stillness and silence of the earlier rocks and branches seemed to stifle.

It is not surprising, as such, that the foremost theme that is overdetermined by these images is that of the frame, the bracketing that puts all her desert or urban Egyptian images within an orderly box as though she were collecting sea shells at the beach. As her un-spiritual and uncreative Cairo social life became more and more limiting, the tabula rasa of the desert and the petrification of the inanimate objects offered the perfect transition from the turmoil of her prior love-life to the thanatos of World War II. Egypt, although boring, could also provide a sense of contemplation and peace that would recharge her enough to confront the combat she would face in Europe. She was able to "frame" her creativity to a certain extent, as she regrouped in terms of her personal, unique artistic production that broke from both her earlier work within her French surrealist circles in Paris as well as the stylish metropolitan portraitures she conceived in her New York studio. As Patricia Allmer puts it: "Miller's surrealism is focused less on [...] bringing together contradictory realities, but is instead located, or rather dislocated, in nomadic moments of in-betweenness, flux, displacement and dispersion - moments which can be traced along folds, tears, and creases, disruptions and flaws" (Allmer 4). In Oasis (date unknown), for example, the promise of water and rejuvenation is reduced to a tiny frame that is multiplied as though it were another mise-en-abyme through a series of eight horizontally extended frames that get bigger and bigger as though they were part of a Russian doll. Not knowing when or how she would reach her internal oasis, the purgatory she experienced in Egypt can easily be understood in this series of gates to her personal and experiential quests for fulfillment. Similarly, in the famous Excursion to Siwa, the eye of the camera watches from a detached angle surrounded not only by negative space but by utter darkness, 
shaped as an eye, through which one can also read "I", the subject. She captures only the legs of the four desert visitors as if to say that faces and expressions are no longer important: in the faceless desert, only the feet - as means of locomotion and exploration, can provide the tools necessary for flight, growth, and ultimately redemption - either for Nemet's death, for example, or for the stormy apprenticeship phase she experienced with Man Ray.

As Bombardement de la Citadelle, which depicts bombs bursting over the Fortress of St.Malo as seen through a window frame, demonstrates so clearly, once she was in the war, the same frames that had harnessed the vast and timeless expanses of the desert or the emptiness of Miller's Egyptian quotidian, would be filled in, literally, with the explosante fixe that pumped her veins with adrenaline and became a type of raison d'être for her. While she may not have been frenetically active in Egypt and missed being at the heart of the action, her artistic production during her briefly married life with Aziz in Cairo yielded a purifying art that provided her with the foundation and stability to go out into the danger-filled unknown of war-torn Europe armed not only with her very own photographic technique and style but also a newfound focus and confidence. Indeed, her low-keyed Egyptian existence allowed her to crystalize the artistic goals within her as though she were a future butterfly in a cocoon waiting to fly away when the timing was once again right.

\section{BIBLIOGRAPHY}

Allmer, Patricia. “Apertures onto Egypt : Lee Miller's Nomadic Surrealism.” Dada/Surrealism 19

(2013) : number1, article 6, pages (Web) :1-17.

Barthes, Roland. Camera Lucida : Reflections on Photography. New York : Hill and Wang, 1981.

Breton, André. Nadja (1928). Translated by Richard Howard. New York : Grove Press, 1994.

Burke, Carolyn. Lee Miller : A Life. New York : Knopf, 2005.

Carter, Ernestine. Preface Edward R. Murrow ; photographs by Lee Miller and others. Grim Glory:

Pictures of Britain Under Fire. London : Lund Humphries/Scribners, 1941.

Conley, Katharine. Surrealist Ghostliness. Lincoln, NE : University of Nebraska Press, 2013.

Haworth-Booth, Mark. The Art of Lee Miller. New Haven, CT : Yale University Press, 2007.

Janus. Preface to Man Ray, Photographs, Paintings, Objects. New York : Shermer's Visual Library, Norton, 1997.

Livingston, Jane. Lee Miller, Photographer. New York : Thames and Hudson, 1989.

Penrose, Anthony. "Lee Miller, Muse et Artiste Surréaliste" in La Femme s'entête : La Part du féminin dans le surréalisme. Ed. Colvile, Georgiana M. \& Conley, Katharine. Paris : Lachenal \& Ritter, 1998. 127-145.

---. The Lives of Lee Miller. London : Thames and Hudson, 1985. 
Roumette, Sylvain (director). Lee Miller : Through the Mirror. Chicago, Ill : Home Vision Arts, 1995.

\section{NOTES}

1. That was the term suggested by Man Ray, but Lee was far too independent for such a role even though she learned a lot from him.

2. As Carolyn Burke understands it, Lee felt increasingly frustrated by the lack of interest in avant-garde art: "After two years of marriage, Lee flouted as many conventions as she could manage. Surrealism was a guaranteed shocker in Cairo. Some friends had gone so far as to read the books she lent them about the movement, but 'They still don't believe it's true”' (Burke 181).

\section{ABSTRACTS}

"As a spectator, I wanted to explore photography not as a question (a theme) but as a wound," Roland Barthes writes in Camera Lucida. Similarly, in the famous first lines of his surrealist book Nadja, André Breton concluded that the question he should ask himself should be "not who I am, but whom I haunt." Could either of these quotes apply to Lee Miller's aesthetic as well ? While her photographs during her period of "apprenticeship" with Man Ray focused on the female body, and the ones in her studio in New York on elegant portraiture, it is during her period in Egypt when she was married to the wealthy Egyptian businessman Aziz that her photography truly blossomed into her own aesthetic which "married" the humor and the ludic notions of space found in certain Magritte paintings with the curious gaze of the 'other' that she would develop as a photo-journalist during the war. Her photos during her Egyptian period are filled with a restlessness and a thirst for adrenaline that would stoke her wartime experiences.

"Comme Spectator, je ne m'intéressais à la Photographie que par "sentiment"; je voulais l'approfondir, non comme une question (un thème), mais une blessure : je vois, je sens, donc je remarque, je regarde et je pense ", écrit Roland Barthes dans La chambre claire. De même, dans la célèbre ouverture de Nadja, André Breton affirme que ce qui importe n'est pas tant de se demander «qui je suis», mais «qui je hante». En quoi ces deux citations peuvent-elles s'appliquer à l'esthétique de Lee Miller? Après les nus féminins réalisés au cours de la période « d'apprentissage » auprès de Man Ray et les élégants portraits de sa période new-yorkaise, c'est en Egypte, après son mariage avec le riche homme d'affaires Aziz, que Lee Miller met véritablement au point sa propre esthétique, où humour et appréhension ludique de l'espace (qui ne sont pas sans rappeler Magritte) se «marient» au regard curieux de "l'autre ", une dimension que Miller allait explorer plus avant dans son travail de photojournaliste. Ainsi, les photographies de la période égyptienne laissent filtrer une impatience et une soif d'émotion forte qui allaient alimenter le travail de photojournalisme de Miller, quelques années plus tard. 
INDEX

Mots-clés: surréalisme américain, photographie, Lee Miller, Man Ray, Egypte, Paris, New York, explosante fixe

Keywords: American surrealism, photography, Lee Miller, Man Ray, Egypt, Paris, New York, explosante fixe

\section{AUTHORS}

\section{PETER SCHULMAN}

Professor, World Languages and Cultures

Old Dominion University

pschulman@odu.edu 